\title{
HUMAN RESOURCE ANALYTICS KEY ROLE IN DIGITALIZING HR PROCESS IN BUSINESS ORGANIZATIONS: A REVIEW
}

\author{
Ms. Hima Jyothi \\ Ms. Salini Rosaline
}

\begin{abstract}
HR analytics refers to the process of quantifying and visualizing HR data to enhance man power performance. It acquired a sky-high prominence recently in estimating the effectiveness of every HR policy/process in the organization to discern value-added employees and HR activities that enhance the business performance. It is proficient in furnishing data-driven decisions that enhance succession planning and best hiring practices, retain qualified workforce, and measure various HR metrics such as turnover, the employee engagement rate for optimizing job experience, focusing on learning and career development programs. The literature encompasses research journal papers, websites, magazines, blogs that are related to HR Analytics. This paper explores the role of various HR analytics tools/software and HR chatbots with unique features in providing seamless HR digitalization. Digital empowerment in HR is enhanced by the deployment of HR chatbots powered by Artificial Intelligence. This paper unfolds the sample list of HR analytics tools/software and chatbots, their role in HR digitalization, and the companies using them. The review also contributes to find out various challenges in the adoption of HR analytics. It is concluded that HR digitalization through analytics is majorly applied to the basic functions mostly quantitative and needs to be explored to complex and qualitative aspects in HR domain.
\end{abstract}

Keywords: HR analytics, HR digitalization, HR analytics software, HR analytics tools, HR chatbots, HR analytics adoption, Artificial Intelligence, Big data analytics.

\section{INTRODUCTION}

In the present scenario, digitalizing the business operations and streamlining with upgraded technology usher business success. Analytics, a trending tech buzzword in the trading world in recent times, consists of two words 'analysis' and 'statistics'. It refers to an analysis done by applying statistics. In recent years, huge and complex data is generated every second. A digital environment with a huge volume of diverse data (Big data) has been created with an increase in the usage of scientific sensors, the Internet of things (IoT), Internet websites, social networking sites, multimedia applications, and financial companies (Alahakoon et al.; Bendre and Thool; Mohamed et al.). Big Data Analytics (BDA) is used in sectors that are application-oriented such as retail, healthcare, advertising, manufacturing, insurance, transportation, telecommunications, banking, fraud detection, agriculture, tourism, 
and government (Bendre and Thool; Mohamed et al.). It also changes the business research in the areas such as Accounting, Marketing, operational management, Finance, and Supply Chain Management. Big data is useful to deploy and evaluate Human Resource (HR) and also to ameliorate the relation between HR and other functions in organizations (Hamilton and Sodeman; Basha et al.). Big data aids the prediction of the future and enables quick decision-making (Gopal and Juneja). Big data resources play a prominent role in achieving competitive advantage by enhancing the efficiency and effectiveness of organizational market capabilities (Suoniemi et al.). Organizations can outline skill requirements for managing talent and employees can promote skills through data analytics (Do et al.). In finance, data analytics is useful for credit risk analysis, portfolio management, asset pricing, financial fraud detection, volatility modelling, and efficiency analysis, and venture capital investments (Andriosopoulos et al.). In healthcare, data analytics is useful for fast pandemic prediction, disease prediction improvement with analyzing medical results of patients, and patient diagnostics (Galetsi and Katsaliaki). Parallel computing, cloud computing, Hadoop, Spark, Storm, Flink, and map-reduce play a key role in BDA (Mohamed et al.; Tsai et al.). BDA capabilities are associated with operational performance and include infrastructure capabilities, human resource capabilities, and management capabilities (Yasmin et al.). Challenges faced in the creation of value from Business Analytics are i) need of clear analytics strategy and data, ii) smart set of people to impact change as data-controlled culture, iii) consideration of ethics in data and information used for competitive advantage (Vidgen et al.). Big data analytics has multi-facets in business functions such as financial analytics, human resource analytics, marketing analytics, and manufacturing analytics. Different types of analytics in each business function are shown in Figure 1.

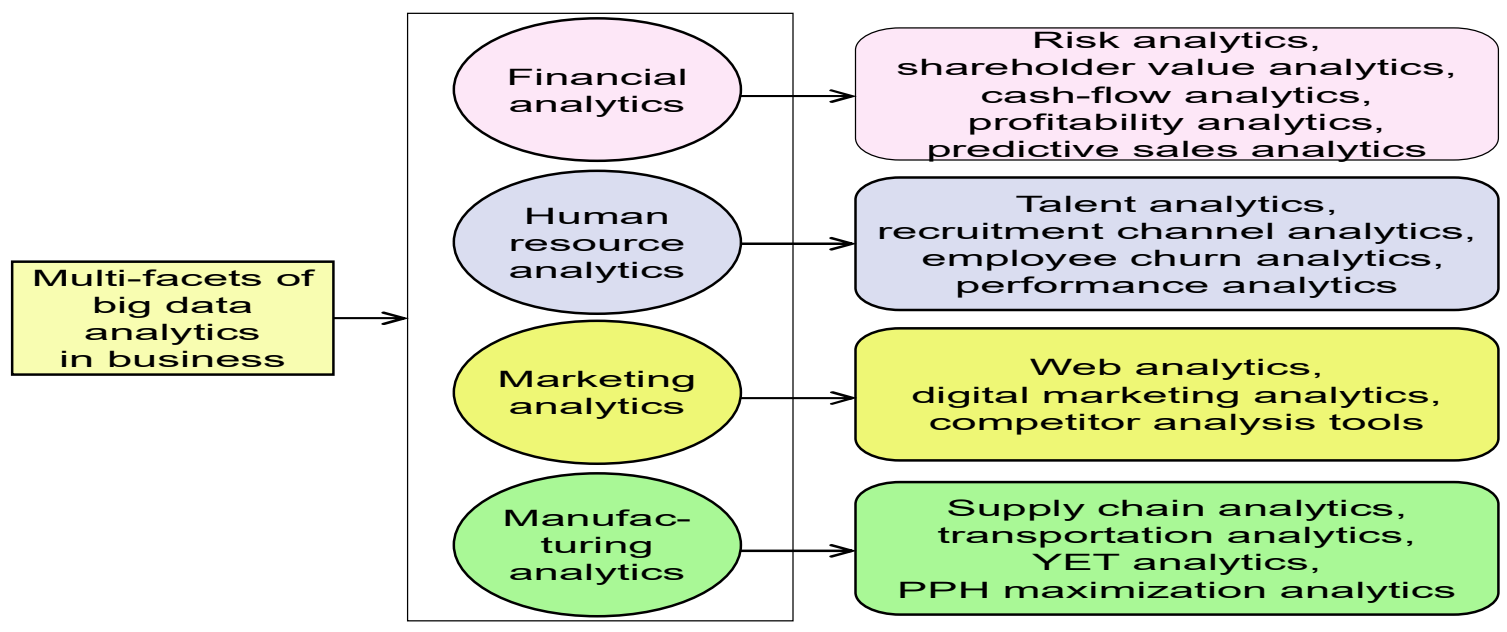


Figure 1 Multi-facets of Big data analytics in business

Analytics applied to the field of HR is referred to as Human Resource analytics. It is the method of collecting and analyzing HR data to enhance employees' performance. As per Bondarouk and Heuvel, HR analytics is the structured identification and quantification of the people who influence the business results (van den Heuvel and Bondarouk). According to Gal, Jensen \& Stein, it is a data-driven methodology to manage the workforce. It enhances the effectiveness of every HR policy/process in the organization to discern value-added employees and HR activities that enhance the business performance. It is proficient in furnishing data-driven decisions that enhance best hiring practices, retaining qualified workforce, predicting the need for the workforce in the future, measuring various HR metrics such as employee turnover, absenteeism rate, cost per hire, the employee engagement rate for optimizing employee job experience, focusing on learning and career development programs for the employees, and maintain records on the learning and certifications of the employees.

As holding a greater number of employees, organizations urge to manage and analyze gigantic employee data effectively and efficiently. Hence, they take the advantage of various digital platforms, HR analytics tools, and software for better handling of large employee data and robust Human Resource Management systems. Analytics India Magazine (AIM) and AnalytixLabs mutually conducted Data Science Skills Survey in June and July months in 2020 for an outlook of key trends in the tools and models availed in different sectors. The survey confessed that 'Python' is the most preferred Language and ' $R$ ' is the second preferred Language in Statistical Modelling. The digital community prefers various HR analytics tools and software with unique features for the seamless digitization of the HR process that support analytics in HR management in organizations. Digital empowerment in Human Resource Management is also enhanced by the deployment of HR chatbots that are equipped with Artificial Intelligence. This paper explores the role of various HR analytics tools/software and HR chatbots with unique features in providing seamless HR digitalization. Digital empowerment in HR is enhanced by the deployment of HR chatbots powered by AI. This paper unfolds the sample list of HR analytics tools and software and HR chatbots, their role in HR digitalization, and the companies using them. The list is prepared by conducting a review on various official blogs related to HR analytics tools/software, and HR chatbots. This 
paper also highlights various challenges faced by organizations in the adoption of HR analytics.

\section{LITERATURE REVIEW}

The major references are summarized into five categories as shown in Figure 2. The categorization is based on theoretical relevance and is termed as applications of big data analytics in different sectors, data analytics role in HR functions, HR analytics concepts and tools, digital transformation through HR analytics tools and chatbots, and their applications. Some of the key research work done by worldwide researchers is described in three aspects.

i. Introductory reviews of 'Digital transformation in HRM' and 'HR analytics'

ii. HR analytics tools and software role in digitalizing HR

iii. HR chatbots role in digitalizing HR

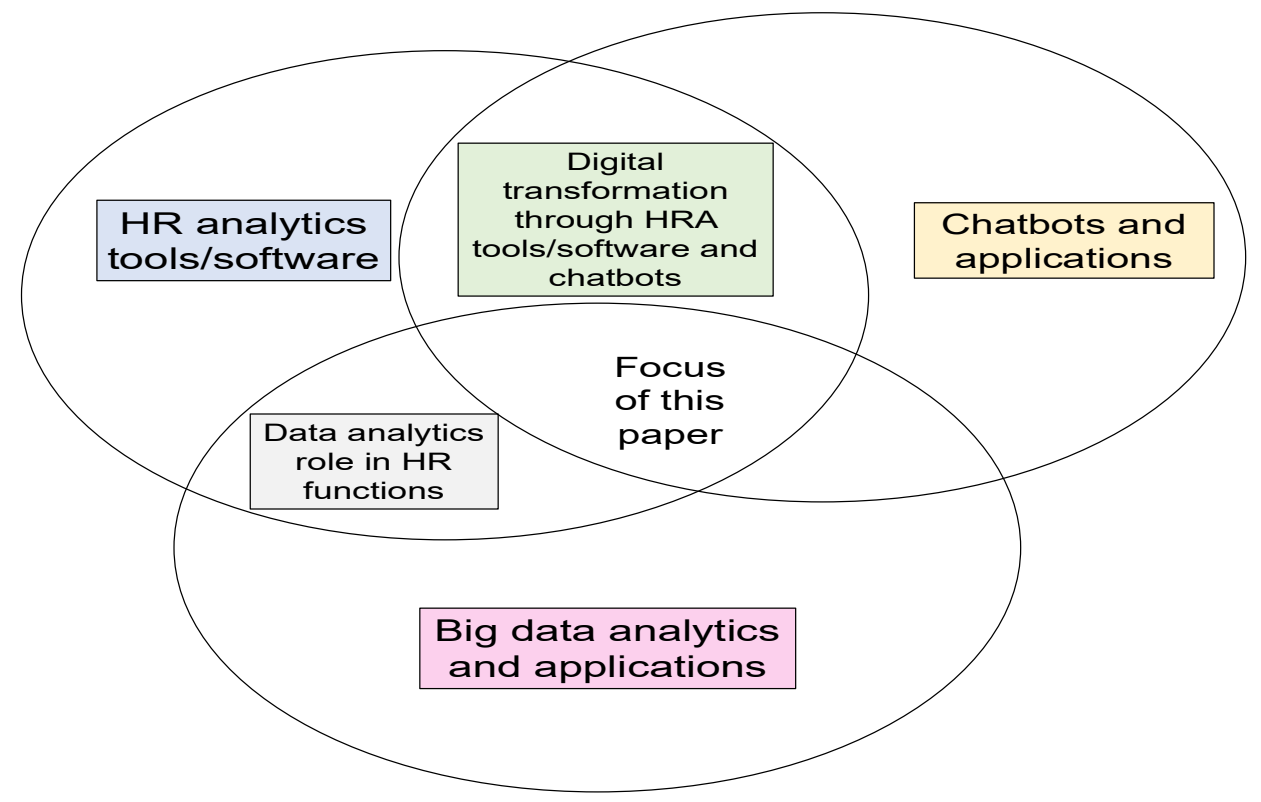

Figure 2 Summary of Literature survey

\section{i. Introductory reviews of 'Digital transformation in HRM' and 'HR analytics'}

HR Analytics is the password for the success of digital transformation in HR functions. The literature review on digital transformation and HR analytics is described as follows.

Organizations adopt digital transformation to improve their customer relationship, attract talent, and arrange them for success (Shah et al.). Digital transformation is an integrated effort to change key processes and services beyond digitization effort (Mergel et al.). It changes the work environment and company culture (Nadkarni and Prügl). Organizational and managerial capabilities are required to drive digital transformation effectively (Li). 
Bharadwaj, Pavlou, Venkatraman, and EI Sawy (2013) termed digital business strategy as the organizational strategy that considers digital resources to generate a differential value (Nsights et al.). Digital business strategy must stabilize its software, process, and information (Bharadwaj et al.). Data analytics, cloud, AI, and blockchain technologies aid the digital transformation of business (Akter et al.).

HR process transformation as automated and data-driven is termed as HR digital transformation. HR digitalization impacts not only HR functions but also the whole organization as well (Verlinden). HRM digitalization impacts firm performance. This impact is enhanced when the HR department highly involve in HR strategies and business (Wang). For HR digitalization and effective use of HR data, the organizations use various types of digital platforms, metrics, and data analysis tools. Using analytical capabilities for analysis and development of insights on HR data is titled HR Analytics. Process analytics (recruitment, selection, work-life balance, competencies, employee opinion surveys, performance management, etc.) and integrated analytics (HR dashboard, succession planning, and Strategic Human Resource Management) are two HR digital insights (Sripathi). There is a prominent impact of IoT on e-HRM in large institutions and industries. E-HRM events such as selection, recruitment, performance, learning, and compensation were purely online. Implementation of policies, practices, and strategies within the organization was done by combining e-HRM and IoT (Nasar et al.). Four mechanisms were suggested to reduce the negative results of algorithm-based decisions in HR. They were ethical awareness, data literacy, private regulatory regimes, and methods of participatory design (Leicht-Deobald et al.). While adopting HR analytics, key ethical principles for respecting employee's privacy and confidentiality, the opportunity for employees to opt-out from HR analytics, set up of review board within the company to discuss the scope of HR analytics, transparency in the communication of data used, and insights generated, adequate statistical skills and data literacy for HR analytics practitioners and respect the personal development of employees was proposed (Simbeck).

\section{ii. HR analytics tools and software role in digitalizing HR}

HR analytics is a practice of HR that analyzes HR data such as human capital, HR process visually and statistically to enhance data-driven decision making (Marler and Boudreau). With the alignment of people analytics with HR Management, the HR department's focus shifts from functional support to strategic requirements of organizations (Tursunbayeva et al.). HR analytics is adopted to understand HR-related investments, 
outcomes, trends, and opportunities. It also helps to analyze data associated with performance management, talent management, and employee engagement. HR Management sets foot in the digital age using various IT and people analytics tools. The tools used in some IT companies are MS Excel, BI world, Taleo (Oracle), Amber, Oracle HCM Cloud, SETU, iRecruit, HRIS, and HRMS (Kakkar and Kaushik). Technological innovation in HR is adopted with the use of various software in people analytics such as Cornerstone, workday, Humanyze, SAP SuccessFactors, Starling Trust, and Greenhouse (Gopal and Juneja). A list of various HR analytics tools/software and their role in HR digitalization are shown in Table 1. HR professionals are provided with HR data insights with the use of HR analytics software such as IBM Kenexa, Oracle HR Analytics, and Talentsoft Analytics, etc. (Capterra). Wipro uses HR Sprinter software to cover HR functions such as learning and development of employees, health, performance, security, and further extended to risk management (Jain and Jain). Bersin J. described nine trends that change the HR software world. They are i) reinvention in performance management, ii) assessment of engagement and its link to performance and feedback, iii) rise in people analytics, iv) increase in learning markets, v) new perspectives in acquiring talent, vi) the rise in gig work such as freelancer and contingent HRM such as workday, Kronos, field-glass, vii) a rise in tools that aid team management combined with HR tools, viii) the boom of apps related to wellness and fitness combined with employee engagement, ix) digital HR enhanced with tools such as Robotic Process Automation (RPA), Artificial Intelligence (AI), and self-service (Bersin). HR analytics model and scoring algorithm were developed in knowledge-based organizations (Stefan et al.). A model is developed to assist HR professionals in decision-making regarding recruitment and placement operations (Pessach et al.). ' $R$ ' is a data analytics tool used in a variety of applications. ' $\mathrm{R}$ ' provides several packages and various features such as versatility, handling large datasets effectively. It provides deep insights by analyzing HR data (Silge, and Robinson).

\section{Challenges:}

The current HR technological system has some limitations such as a system of one-way communication, impersonal, not allowing interpersonal communication, and creating distance between organizations and individuals in reaching HR goals (attract, retain, motivate employees) (Stone et al.). Some of the challenges faced by workforce analytics are data analytics skills shortage in HR, insufficient investment in analytics from business, poor IT infrastructure (Zeidan and Itani). By overcoming various challenges, HR analytics will 
Towards Excellence: An Indexed, Refereed \& Peer Reviewed Journal of Higher Education /

Ms. Hima Jyothi \& Ms. Salini Rosaline/ Page 76-93

become a prominent discipline by 2025 and it will integrate with IT infrastructure and data across disciplines and organizational boundaries (van den Heuvel and Bondarouk).

Table 1 List of HR analytics tools/software

\begin{tabular}{|c|c|c|c|}
\hline Reference & $\begin{array}{l}\text { HR Analytic } \\
\text { HRA) } \\
\text { lool/software }\end{array}$ & $\begin{array}{l}\text { Digitized HR Process using } \\
\text { HRA tool/software }\end{array}$ & $\begin{array}{l}\text { Companies using } \\
\text { tool/software }\end{array}$ \\
\hline \multirow{15}{*}{$\begin{array}{l}\text { (Slintel; } \quad \text { Tech } \\
\text { Funnel) }\end{array}$} & BambooHR & $\begin{array}{l}\text { Performance Management, e- } \\
\text { signatures, } \quad \text { Attendance } \\
\text { tracking }\end{array}$ & $\begin{array}{l}\text { Hyundai Heavy Industries, Nortek, } \\
\text { White Castle, Dell EMC }\end{array}$ \\
\hline & Jobvite & Recruitment & $\begin{array}{l}\text { Swift Transportation Corp., Ingram } \\
\text { Micro, Kasina }\end{array}$ \\
\hline & Oracle Taleo & $\begin{array}{l}\text { Talent acquisition, retention, } \\
\text { development }\end{array}$ & $\begin{array}{l}\text { International SOS, Intercat, Olin } \\
\text { Corporation }\end{array}$ \\
\hline & Greenhouse & HR administration & Taco Bell, NTT Data, Oak Bell, \\
\hline & Workable & Recruitment & $\begin{array}{l}\text { Ipsos, Johnson Electric, Atb } \\
\text { Financial, Access Bank }\end{array}$ \\
\hline & iCIMS & $\begin{array}{l}\text { Recruitment, } \\
\text { Communication }\end{array}$ & Holcim, Quanta Services, Foglight \\
\hline & $\begin{array}{l}\text { ClearCompan } \\
\mathrm{y}\end{array}$ & $\begin{array}{lr}\begin{array}{l}\text { Recruitment, } \\
\text { planning, }\end{array} & \begin{array}{l}\text { workforce } \\
\text { performance }\end{array} \\
\text { management } & \\
\end{array}$ & Bosch, Axiom Bank, Benco Dental \\
\hline & Recruiterbox & Recruitment & $\begin{array}{l}\text { Berlitz, Centric Digital, Compass, } \\
\text { almabase }\end{array}$ \\
\hline & $\begin{array}{l}\text { ApplicantSta } \\
\text { ck }\end{array}$ & $\begin{array}{l}\text { Recruitment, onboarding, } \\
\text { payroll management }\end{array}$ & $\begin{array}{l}\text { CRC, Human Capital, HR Strategy } \\
\text { Group }\end{array}$ \\
\hline & Avature & Recruitment, Communication & $\begin{array}{l}\text { General Dynamics Land Systems } \\
\text { Inc., Red Bull GmbH }\end{array}$ \\
\hline & $\begin{array}{l}\text { SAP } \\
\text { SuccessFacto } \\
\text { rs }\end{array}$ & $\begin{array}{l}\text { Employee engagement, } \\
\text { payroll management }\end{array}$ & $\begin{array}{l}\text { Blue Lab, Metlife, Sonae, Arla } \\
\text { Foods }\end{array}$ \\
\hline & JazzHR & $\begin{array}{l}\text { candidate assessment, job } \\
\text { posting, reporting, e-signature }\end{array}$ & $\begin{array}{l}\text { Lionbridge, Veon, Samsung Global } \\
\text { Strategy Group }\end{array}$ \\
\hline & ZohoRecruit & $\begin{array}{l}\text { Resume storage and parsing, } \\
\text { Interview scheduling }\end{array}$ & Airtel, SpiceJet, Penn, OnePlus \\
\hline & $\begin{array}{l}\text { Kronos } \\
\text { Workforce } \\
\text { ready }\end{array}$ & $\begin{array}{l}\text { Labor cost management, } \\
\text { performance management, } \\
\text { compensation management, } \\
\text { workforce } \\
\text { employee time tracking }\end{array}$ & $\begin{array}{l}\text { Tony Downs Foods, MedSpeed, } \\
\text { Aspen Skiing Company }\end{array}$ \\
\hline & Bullhorn & Recruitment and staffing & eHire, FocusCore, AUREC Group \\
\hline \multirow{2}{*}{$\begin{array}{l}(\mathrm{G} 2 ; \quad \text { Bigdata } \\
\text { made simple })\end{array}$} & $\begin{array}{l}\text { Aurion } \\
\text { Analytics }\end{array}$ & $\begin{array}{l}\text { visualization of data insights, } \\
\text { dashboards, payroll }\end{array}$ & $\begin{array}{l}\text { Elmo Cloud Hr \& Payroll, Chandler } \\
\text { Macleod }\end{array}$ \\
\hline & $\begin{array}{l}\text { Oracle HR } \\
\text { Analytics }\end{array}$ & $\begin{array}{l}\text { Employee performance } \\
\text { analysis, encouragement }\end{array}$ & $\begin{array}{l}\text { Pepper Group, American Eagle } \\
\text { Outfitters, Inc., Macy's Inc. }\end{array}$ \\
\hline
\end{tabular}


Towards Excellence: An Indexed, Refereed \& Peer Reviewed Journal of Higher Education /

Ms. Hima Jyothi \& Ms. Salini Rosaline/ Page 76-93

\begin{tabular}{|c|c|c|c|}
\hline & Crunchr & $\begin{array}{l}\text { Employee } \\
\text { business experience and } \\
\text { improvement }\end{array}$ & Naspers, randstad, nets, GrandVision \\
\hline $\begin{array}{l}\text { (Slintel; Bigdata } \\
\text { made simple; } \\
\text { Infoclutch) }\end{array}$ & IBM Kenexa & $\begin{array}{l}\text { talent analytics, performance } \\
\text { management, talent } \\
\text { acquisition, and management }\end{array}$ & $\begin{array}{l}\text { Mayo Clinic, Sears, Lowe's, CVS } \\
\text { Health }\end{array}$ \\
\hline $\begin{array}{l}(\mathrm{G} 2 ; \\
\text { Funnel) }\end{array}$ & ADP & $\begin{array}{l}\text { talent management, payroll } \\
\text { management, time and labor } \\
\text { management, employee } \\
\text { documents scanning, storing, } \\
\text { and searching }\end{array}$ & $\begin{array}{l}\text { Genesis HealthCare, } \quad \text { Ferro } \\
\text { Corporation, Infinera Corporation }\end{array}$ \\
\hline \multirow{3}{*}{ (Tech Funnel) } & $\begin{array}{l}\text { SmartF } \\
\text { ers }\end{array}$ & $\begin{array}{l}\text { talent acquisition, } \\
\text { communication }\end{array}$ & $\begin{array}{lll}\text { American Iron\&Metal, Allegis } \\
\text { Global Solutions, Indigo }\end{array}$ \\
\hline & Paylocity & $\begin{array}{l}\text { Monitoring compensation and } \\
\text { benefits, storing employee } \\
\text { data }\end{array}$ & $\begin{array}{l}\text { Dynex Technologies, Snider Fleet } \\
\text { Solutions, Kocher+Beck USA LP }\end{array}$ \\
\hline & Recooty & Hiring & $\begin{array}{l}\text { Uber, American Hospital, Sendlane, } \\
\text { Airtable }\end{array}$ \\
\hline \multirow{3}{*}{$\begin{array}{l}\text { (Bigdata made } \\
\text { simple) }\end{array}$} & $\begin{array}{l}\text { Talent } \\
\text { ytics }\end{array}$ & $\begin{array}{l}\text { converting employee data } \\
\text { into a dashboard }\end{array}$ & Bunker Holding, CarGlass, Shurgard \\
\hline & PeopleInsight & HR dashboards, analytics & $\begin{array}{l}\text { CBRE Ltd., Alliance, Healthcare } \\
\text { services }\end{array}$ \\
\hline & $\begin{array}{l}\text { People } \\
\text { Analytics by } \\
\text { TrenData }\end{array}$ & $\begin{array}{l}\text { Workforce } \\
\text { dashboards }\end{array}$ & $\begin{array}{l}\text { OrthoTexas, DuraServ Corporation, } \\
\text { MemorialCare Health }\end{array}$ \\
\hline (Slintel) & Ultipro & $\begin{array}{l}\text { Recruitment, } \\
\text { management }\end{array}$ & BROKERLINK, Pethealth Inc. \\
\hline $\begin{array}{l}\text { (G2; Vulpen } \\
\text { E.V.) }\end{array}$ & Visier & $\begin{array}{l}\text { Workforce planning, talent } \\
\text { acquisition }\end{array}$ & $\begin{array}{l}\text { BBVA, Anglo American, Merck } \\
\text { KGaA, Experian }\end{array}$ \\
\hline \multirow{3}{*}{ (Vulpen E.V.) } & $\mathrm{R}$ & $\begin{array}{l}\text { Visualization of HR data } \\
\text { analysis, insights }\end{array}$ & $\begin{array}{l}\text { Google, IBM, Facebook, Microsoft, } \\
\text { New York Times }\end{array}$ \\
\hline & Python & $\begin{array}{l}\text { Visualization of HR data } \\
\text { analysis, insights }\end{array}$ & $\begin{array}{l}\text { Google, IBM, Quora, Facebook, } \\
\text { Instagram }\end{array}$ \\
\hline & Tableau & $\begin{array}{l}\text { Visualization of HR data } \\
\text { analysis, insights }\end{array}$ & $\begin{array}{l}\text { The Boeing Company, Experian, } \\
\text { UNICEF - New York }\end{array}$ \\
\hline
\end{tabular}

\section{iii. HR chatbots role in digitalizing HR}

AI and Robotics play a key role in the automation of routine HR processes (Gopal and Juneja). Organizations automate structured and routine processes with digital inputs and rulebased systems. RPA empowers automation of a business process that is rule-based by using software bots (Kokina and Blanchette). The use of chatbots equipped with AI is increased in many fields. A chatbot is a computer software program that uses Natural Language Processing and AI. It extracts and emanates useful information to answer the queries of humans (Mohan). Various application domains of chatbots are E-customer service, E- 
learning, E-commerce, work and career, daily life, and finance (Breitner et al.). Many Ecommerce companies use live chat interfaces to communicate with their customers. Chatbots are used to replace the agents of human chat service (Adam and Adam). They are also used to provide customer service in hospitality management (Carter et al.). In Accounting and Finance areas, RPA is implemented with the use of bots. The accountant's role is changed to expand their skillset, robotic software development, support, and testing (Kokina and Blanchette). HR teams begin to use AI for the automation of chore of recruitment (Melder). Many job-seeking candidates are interested in using the AI-enabled recruitment process (Esch and Black). Primary HR chatbot in India, Jinie that was developed by People Strong Company assists in employee work-related queries (Amla and Malhotra). HR chatbots disrupt HR in areas such as Frequently Asked Questions, common questions, Recruitment, onboarding, training, benefits enrollment, and reviews. Human-chatbot communications significantly differ in conversation content and quality when compared with human-human conversations online (Hill et al.).

\section{Challenges:}

As per Parlo Magazine (2018) when it is decided to use bots in HR, the challenges that have to be considered are information security, legal boundaries, extensibility, and audit logging.

Table 2 List of HR chatbots used for HR digitalization

\begin{tabular}{|c|c|c|c|}
\hline Reference & $\begin{array}{l}\text { HR } \\
\text { Chatbot }\end{array}$ & Role of HR Chatbot in HR & Companies using HR Chatbot \\
\hline (Leena AI) & Leena & $\begin{array}{l}\text { Employee engagement, Automation } \\
\text { of FAQ, WFH surveys }\end{array}$ & $\begin{array}{l}\text { Sony, Nestle, Tata Technologies, } \\
\text { OnePlus }\end{array}$ \\
\hline (Mya) & Mya & $\begin{array}{l}\text { Recruitment process automation, } \\
\text { Career site Engagement, Retention }\end{array}$ & $\begin{array}{l}\text { LOREAL, SevenStep, Deloitte, } \\
\text { Advantage Solutions }\end{array}$ \\
\hline \multirow{2}{*}{$\begin{array}{l}\text { (selectsoftware } \\
\text { reviews) }\end{array}$} & XOR & $\begin{array}{l}\text { Recruiting, onboarding, Surveys, } \\
\text { Scheduling }\end{array}$ & $\begin{array}{l}\text { Novus, IKEA, Talint, MARS, HR } \\
\text { Maximizer, TalentBoard }\end{array}$ \\
\hline & Olivia & People engagement, Recruitment & $\begin{array}{l}\text { DFCU Financial, Koch Trucking, } \\
\text { U.S. Express, First Watch, Visiting } \\
\text { Angels }\end{array}$ \\
\hline (Talkpush) & Talkpush & Recruitment & $\begin{array}{l}\text { McDonald's, Transcom, iQor, } \\
\text { alorica, Adecco }\end{array}$ \\
\hline $\begin{array}{l}\text { (Wadeandwend } \\
\text { y) }\end{array}$ & $\begin{array}{l}\text { Wade and } \\
\text { Wendy }\end{array}$ & Recruitment & $\begin{array}{l}\text { RandStad, Tquila, WeCrewt, } \\
\text { Evolution Service Corp, Comcast }\end{array}$ \\
\hline (Ideal) & Ideal & Recruitment & $\begin{array}{l}\text { S\&P Data, Indigo Books \& Music, } \\
\text { Ideal Image }\end{array}$ \\
\hline $\begin{array}{l}\text { ("Conversation } \\
\text { al AI \& }\end{array}$ & Allyo & $\begin{array}{l}\text { Employee engagement and } \\
\text { communication }\end{array}$ & $\begin{array}{l}\text { Randstad, Staples, The Andersons, } \\
\text { Residential, Southern Cross }\end{array}$ \\
\hline
\end{tabular}




\begin{tabular}{|c|c|c|c|}
\hline $\begin{array}{l}\text { Recruitment } \\
\text { Automation } \\
\text { Hirevue") }\end{array}$ & & & \\
\hline (Eightfold.ai) & eightfold & Talent management & $\begin{array}{l}\text { Micron, Coit, Air Asia, Twilio, } \\
\text { NextRoll }\end{array}$ \\
\hline (Brazen) & Brazen & Talent acquisition & $\begin{array}{l}\text { Houston Methodist, Spectrum, } \\
\text { CSRA, Bucknell University }\end{array}$ \\
\hline $\begin{array}{l}\text { ("Sara HR } \\
\text { Chatbot, Smart } \\
\text { HR Chatbot, } \\
\text { AI Bots In HR } \\
\text { Software") }\end{array}$ & Sara & $\begin{array}{l}\text { Payroll, Talent management, HR } \\
\text { Analytics, Learning Management } \\
\text { System }\end{array}$ & $\begin{array}{l}\text { Honda, Nissan, Suzuki, IIFL, } \\
\text { Apollo, Epson, }\end{array}$ \\
\hline (Moon) & MooN & $\begin{array}{l}\text { FAQ, HR Queries, Training, } \\
\text { Engagement, Pre-boarding, On- } \\
\text { boarding, Happiness Index }\end{array}$ & $\begin{array}{l}\text { Allen Solly, Kellogg's, ITC, } \\
\text { Britannia, Duracell }\end{array}$ \\
\hline
\end{tabular}

\section{MATERIALS AND METHODS}

The literature review encompasses research journal papers, blogs, websites, magazines, company reports, and surveys that are related to HR Analytics. The keywords used to accompany this review were HR analytics, HR analytics tools, and software, Technologydriven HRM, e-HRM, HR chatbots. This paper was inscribed by reviewing 45 articles published from 2013 to 2020 that were selected from Elsevier, Wiley, Taylor, and Francis, Springer, IEEE Xplore, Science Direct, etc. The articles are selected from standard journals such as Journal of Business Research, Business Horizons, Journal of Management Analytics, International Journal on Arts, Management and Humanities, International Journal of Human Resource Management, etc. Various official blogs, websites, magazines, and reports were reviewed to list out various HR analytics tools and software and HR chatbots equipped with AI that enhance the HR digitalization process.

\section{RESULTS AND DISCUSSION}

From the review, it is revealed that HR Analytics is the password for the success of digital transformation in HR. From the results, it is evident that HR analytics software is adopted extremely for routine/basic HR operations such as Applicant Tracking System/Recruitment (includes talent acquisition, onboarding, scheduling interviews, communication, Resume storage and parsing), FAQ (Candidate/Employee HR-related queries), and Learning Management System (Training/ Learning and development), etc. BambooHR, IBM Kenexa, ClearCompany, and Kronos Workforce are used for performance management. Payroll is 
better managed by using ADP, SAP SuccessFactors, and ApplicantStack. Leena, Allyo, AskHR are some of the chatbots that aid employee engagement. As to the end-user industry, retail, healthcare, BFSI, government, IT \& telecom, education, and manufacturing can be divisions in the HR analytics market. Based on Transparencymarketresearch, 2020, in the HR analytics global market world, key players include Accenture plc, Cognizant, IBM Corporation, Infosys Limited, Kenexa Corporation, Genpact Ltd., Beeline, Paylocity, Kronos, Inc., Oracle Corporation, GainInsights Solutions, Nakisa, Inc., PeopleAdmin, Tableau Software Inc., SAP SE, Visier, WorkForce, SumTotal Systems Inc., TALENTSOFT, ADP LLC, Taleo Corporation, and Workday. HR digitalization through HR analytics is majorly applied to the routine/basic functions especially quantitative data generating HR functions, it must be explored to complex and qualitative data generating HR areas such as diversity analytics. For effective implementation of HR data analytics, data-driven storytelling is a communication tool that conveys critical insights to the ultimate decision-makers to drive action (Labrosse).

HR analytics has two facets like a coin. On one side, some organizations reap benefits from the effective adaptation of HR analytics and open doors for analyzing new opportunities. Organizations improve their employee experience, retention rate, training effectiveness, and acquire talent by using the best hiring practices. HR analytics provide deep insights into the data and enhances effective decision-making. On the other side, some organizations are facing various challenges in adapting HR analytics. There are various challenges in the implementation of HR analytics in business organizations based on whether they are operating on a large scale or small scale. The basic differences observed particularly in HR between large and small organizations are categorized into four ways such as availability of resources, HR processes such as recruitment and retention, level of responsibility, and organizational structure (Dudjarejia). According to Transparencymarketresearch, 2020, the adaption rate of HR analytics is more in large organizations when compared with small organizations. Gaur M. and Tomar S. proposed four challenges in the implementation of HR analytics such as data governance, data quality issues, skill gap, and top management support (Tomar and Gaur). Other challenges posed by HR analytics are data cleansing, excess of data leading to lack of clarity, lack of data analytics skills, deciding suitable HR tools to keep track of the data, data privacy, and compliance (Rangaiah). 


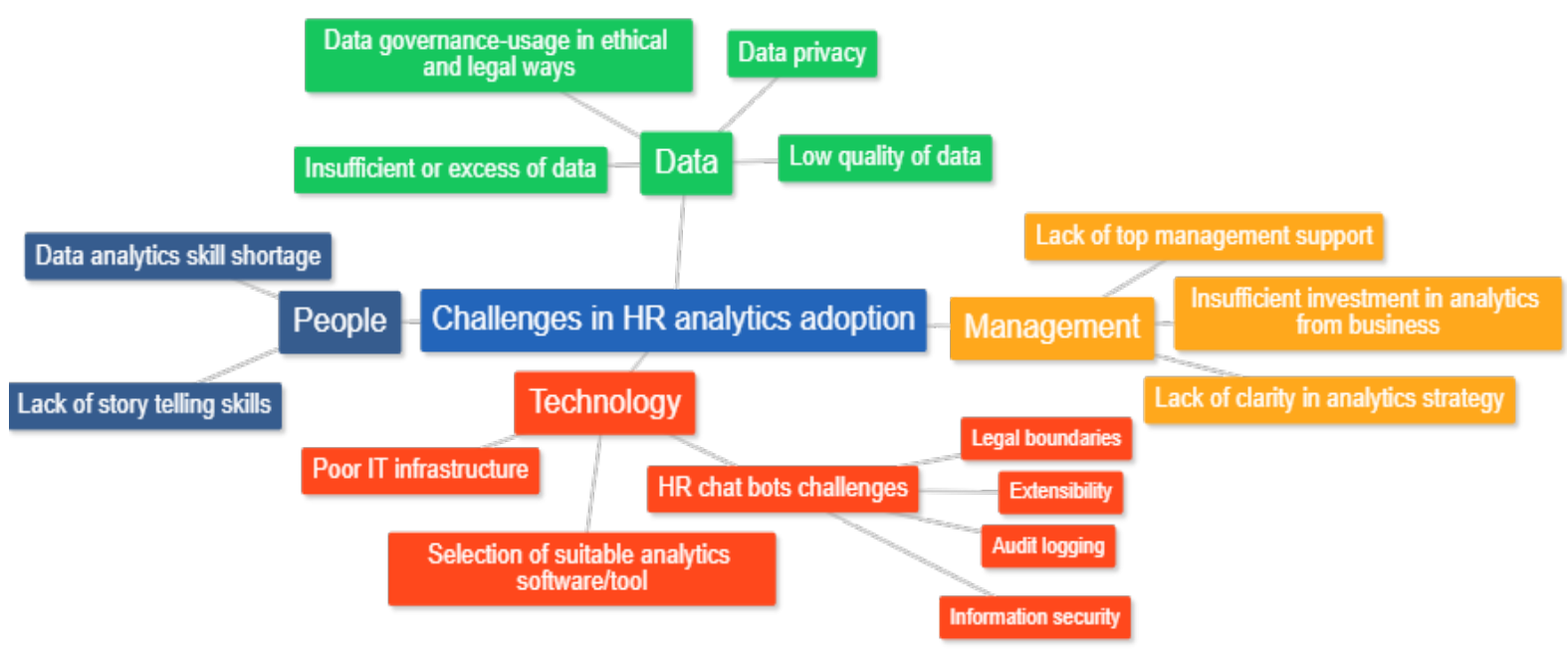

Figure 3.Various challenges in the adoption of HR Analytics, identified from the literature

\section{CONCLUSION AND FUTURE SCOPE}

Organizations are digitalizing their HR functions to reduce the routine workload on HR professionals with the use of various HR analytics tools, software, and bots and utilize the time for complex HR issues. Organizations are still striving to use qualitative data to get fruitful results from HR analytics. Finally, it is concluded that HR analytics plays a vital role in the HR digitization process in an extant business scenario. This paper highlights various HR analytics tools, software, and chatbots used in organizations and various challenges faced by organizations in implementing HR analytics.

There is much scope to inscribe research articles on HR analytics (Marler and Boudreau). Research work in HR analytics needs to be extended to various sectors and the pros and cons of implementation of HR analytics need to be explored. HR analytics' role in analyzing qualitative data such as diversity analytics has scope for conducting further research. 
Towards Excellence: An Indexed, Refereed \& Peer Reviewed Journal of Higher Education /

Ms. Hima Jyothi \& Ms. Salini Rosaline/ Page 76-93

\section{References}

\section{Journal papers}

Adam, Martin, and Martin Adam. AI-Based Chatbots in Customer Service and Their Effects on User Compliance. Electronic Markets, 2020.

Akter, Shahriar, et al. "Transforming Business Using Digital Innovations : The Application of AI , Blockchain , Cloud and Data Analytics." Annals of Operations Research, Springer US, 2020, doi:10.1007/s10479-020-03620-w.

Alahakoon, Damminda, et al. Self-Building Artificial Intelligence and Machine Learning to Empower Big Data Analytics in Smart Cities. Information Systems Frontiers, 2020.

Amla, Manju, and Prof Meenakshi Malhotra. Digital Transformation in HR. no. 3, 2017, pp. 536-44.

Andriosopoulos, Dimitris, et al. "Computational Approaches and Data Analytics in Financial Services: A Literature Review." Journal of the Operational Research Society, vol. 70, no. 10, Taylor \& Francis, 2019, pp. 1581-99, doi:10.1080/01605682.2019.1595193.

Basha, Syed Muzamil, et al. Recent Trends in Sustainable Big Data Predictive Analytics: Past Contributions and Future Roadmap. no. 2, 2019, pp. 50-59.

Bendre, Mininath R., and Vijaya R. Thool. Analytics, Challenges and Applications in Big Data Environment : A Survey. no. July, 2016, doi:10.1080/23270012.2016.1186578.

Bharadwaj, Anandhi S., et al. VISIONS AND V OICES ON E MERGING C HALLENGES IN. no. June, 2013, doi:10.25300/MISQ/2013/37.2.14.

Breitner, Michael H., et al. Virtual Assistance in Any Context. no. 3, 2020, pp. 211-25, doi:10.1007/s12599-020-00644-1.

Carter, Emma, et al. Chatbots - an Organisation's Friend or Foe? Chatbots - an Organisation 's Friend or Foe? 2019, doi:10.1080/22243534.2019.1689700.

Do, Michael D., et al. "ScienceDirect ScienceDirect ScienceDirect Leveraging People Analytics for an Adaptive Complex Talent Management Leveraging People Analytics for an Adaptive Complex Talent Management System System.” Procedia Computer Science, vol. 168, no. 2019, Elsevier B.V., 2020, pp. 105-11, doi:10.1016/j.procs.2020.02.269.

Esch, Patrick Van, and J. Stewart Black. "ScienceDirect Factors That Influence New Generation Candidates to Engage with and Complete Digital , AI-Enabled Recruiting." Business Horizons, vol. 1975, no. xxxx, Elsevier Ltd, 2019, doi:10.1016/j.bushor.2019.07.004.

Galetsi, Panagiota, and Korina Katsaliaki. "A Review of the Literature on Big Data Analytics 
in Healthcare." Journal of the Operational Research Society, vol. 0, no. 0, Taylor \& Francis, 2019, pp. 1-19, doi:10.1080/01605682.2019.1630328.

Gopal, R., and Abhya Juneja. The Impact of Technology in HR: The Road Ahead. no. 2, 2017, pp. 219-21.

Hamilton, R. H., and William A. Sodeman. "ScienceDirect The Questions We Ask: Opportunities and Challenges for Using Big Data Analytics to Strategically Manage Human Capital Resources." Business Horizons, no. $\quad \operatorname{xxxx,~Elsevier~Ltd,~2019,~}$ doi:10.1016/j.bushor.2019.10.001.

Hill, Jennifer, et al. "Computers in Human Behavior Real Conversations with Artificial Intelligence : A Comparison between Human - Human Online Conversations and Human Chatbot Conversations." COMPUTERS IN HUMAN BEHAVIOR, vol. 49, Elsevier Ltd, 2015, pp. 245-50, doi:10.1016/j.chb.2015.02.026.

Jain, Pooja, and Pranjal Jain. Understanding the Concept of HR Analytics 1. no. 2, 2020, pp. 644-52.

Kakkar, Hargovind, and Sanjay Kaushik. Technology Driven Human Resource Measurement-A Strategic Perspective. 2019, pp. 179-84.

Kokina, Julia, and Shay Blanchette. "International Journal of Accounting Information Systems Early Evidence of Digital Labor in Accounting: Innovation with Robotic Process Automation." International Journal of Accounting Information Systems, no. xxxx, Elsevier Inc., 2019, p. 100431, doi:10.1016/j.accinf.2019.100431.

Labrosse, Michelle. Project Management The Traction of Success. 2008, pp. 83-88, doi:10.1002/ert.

Leicht-Deobald, Ulrich, et al. "The Challenges of Algorithm-Based HR Decision-Making for Personal Integrity." Journal of Business Ethics, vol. 160, no. 2, Springer Netherlands, 2019, pp. 377-92, doi:10.1007/s10551-019-04204-w.

Li, Liang. Digital Transformation by SME Entrepreneurs: A Capability Perspective. no. February 2016, 2017, pp. 1-29, doi:10.1111/isj.12153.

Marler, Janet H., and John W. Boudreau. "An Evidence-Based Review of HR Analytics An Evidence-Based Review of HR Analytics." The International Journal of Human Resource Management, vol. 5192, Routledge, 2017, pp. 1-24, doi:10.1080/09585192.2016.1244699.

Mergel, Ines, et al. "Defining Digital Transformation : Results from Expert Interviews Government Information Quarterly, no. June, Elsevier, 2019, p. 101385, doi:10.1016/j.giq.2019.06.002. 
Mohamed, Azlinah, et al. "The State of the Art and Taxonomy of Big Data Analytics : View from New Big Data Framework." Artificial Intelligence Review, no. 0123456789, Springer Netherlands, 2019, doi:10.1007/s10462-019-09685-9.

Mohan, Reenu. "The Chatbot Revolution and the Indian HR Professionals." International Journal of Information and Computing Science, vol. 6, no. 3, 2019, pp. 489-99.

Nadkarni, Swen, and Reinhard Prügl. “And Opportunities for Future Research.” Management Review Quarterly, no. 0123456789, Springer International Publishing, 2020, doi:10.1007/s11301-020-00185-7.

Nasar, Nasreen, et al. "Design and Data Analytics of Electronic Human Resource Management Activities through Internet of Things in an Organization." Software - Practice and Experience, no. February, 2020, pp. 1-17, doi:10.1002/spe.2817.

Nsights, G. Eneration O. F. I., et al. D IGITAL B USINESS S TRATEGY:T OWARD A N EXT. no. 2, 2013, pp. 471-82.

Pessach, Dana, et al. "Employees Recruitment: A Prescriptive Analytics Approach via Machine Learning and Mathematical Programming." Decision Support Systems, vol. 134, no. April, Elsevier, 2020, p. 113290, doi:10.1016/j.dss.2020.113290.

Shah, Saleh, et al. "Compromised User Credentials Detection in a Digital Enterprise Using Behavioral Analytics." Future Generation Computer Systems, Elsevier B.V., 2018, doi:10.1016/j.future.2018.09.064.

Simbeck, K. "HR Analytics and Ethics." IBM Journal of Research and Development, vol. 63, no. 4-5, 2019, p. 1, doi:10.1147/JRD.2019.2915067.

Sripathi, Kalvakolanu. A New Wave of Digitalizing Hr : Hr Analytics. no. 04, 2018, pp. 10312, doi:10.5281/zenodo.4452026.

Stefan, Sergiu, et al. "Human Capital Evaluation in Knowledge-Based Organizations Based on Big Data Analytics." Future Generation Computer Systems, no. xxxx, Elsevier B.V., 2019, doi:10.1016/j.future.2019.09.048.

Stone, Dianna L., et al. "Human Resource Management Review The In Fl Uence of Technology on the Future of Human Resource Management." Human Resource Management Review, Elsevier Inc., 2015, pp. 1-16, doi:10.1016/j.hrmr.2015.01.002.

Suoniemi, Samppa, et al. "Information \& Management Big Data and Firm Performance: The Roles of Market-Directed Capabilities and Business Strategy." Information \& Management, vol. 57, no. 7, Elsevier B.V., 2020, p. 103365, doi:10.1016/j.im.2020.103365.

Tomar, Shivam, and Mamta Gaur. HR Analytics in Business: Role, Opportunities, and 
Challenges of Using It . no. August, 2020, doi:10.37896/JXAT12.07/2441.

Tsai, Chun Wei, et al. "Big Data Analytics: A Survey." Journal of Big Data, Springer International Publishing, 2015, pp. 1-32, doi:10.1186/s40537-015-0030-3.

Tursunbayeva, Aizhan, et al. "International Journal of Information Management People Analytics - A Scoping Review of Conceptual Boundaries and Value Propositions." International Journal of Information Management, vol. 43, no. July, Elsevier, 2018, pp. 22447, doi:10.1016/j.ijinfomgt.2018.08.002.

van den Heuvel, Sjoerd, and Tanya Bondarouk. "The Rise (and Fall?) Of HR Analytics: A Study into the Future Application, Value, Structure, and System Support." Journal of Organizational Effectiveness, vol. 4, no. 2, 2017, pp. 157-78, doi:10.1108/JOEPP-03-20170022 .

Vidgen, Richard, et al. "PT US CR.” European Journal of Operational Research, Elsevier B.V., 2017, doi:10.1016/j.ejor.2017.02.023.

Wang, Lijun. The Impact of HRM Digitalization on Firm Performance : Investigating ThreeWay Interactions. no. 59, 2020, doi:10.1111/1744-7941.12258.

Yasmin, Mariam, et al. "Big Data Analytics Capabilities and Firm Performance: An Integrated MCDM Approach.” Journal of Business Research, vol. 114, no. February, Elsevier, 2020, pp. 1-15, doi:10.1016/j.jbusres.2020.03.028.

Zeidan, S., and N. Itani. HR Analytics and Organizational Effectiveness 1. no. 2, 2020, pp. $683-88$.

\section{Websites}

Silge, J. and Robinson, D., 2017. Text mining with R. Sebastopol, CA: O'Reilly Media.

"Conversational AI \& Recruitment Automation | Hirevue". Hirevue.Com, 2020, https://www.allyo.com/?ssrid=ssr.

"Sara HR Chatbot, Smart HR Chatbot, AI Bots In HR Software". Myadrenalin.Com, 2020, https://www.myadrenalin.com/sara-hr-chatbot/

Bersin, J. Perspective | 2016 HR Technology Disruptions for 2017: Nine Trends Reinventing the HR Software Market, 2017, pp. 1-49. https://www.ig.cl/wp-content/uploads/2016/11/HRTechnology-trends-2016-by-Bersin.pdf

Bigdata made simple. Top 10 HR Analytics tools in 2018. 2018, https://bigdatamadesimple.com/top-10-hr-analytics-tools-in-2018/

Brazen. Recruiting Chatbots: The Definitive Guide. 2020, https://www.brazen.com/recruiting-chatbots-the-definitive-guide 
Capterra. HR Analytics Software. 2020, https://www.capterra.com/hr-analytics-software/

Dudjarejia, M. 4 ways HR is different for small businesses than for large organizations. 2019, https://keap.com/business-success-blog/business-management/human-resources/howhr-differs-from-small-to-big-biz

Eightfold.ai. Customers. 2020, https://eightfold.ai/?ssrid=ssr

G2. Best HR Analytics Software. 2020, https://www.g2.com/categories/hr-analytics

Ideal. A How-To Guide For Using A Recruitment Chatbot. 2020, https://ideal.com/recruitment-chatbot/

Infoclutch. IBM Kenexa Customers List. 2020, https://www.infoclutch.com/installedbase/hrms/ibm-kenexa/

Leena AI. Resources. 2020, https://leena.ai/

Melder, B. The Role of Artificial Intelligence (AI) in Recruitment. TalentLyft., 2018, https://www.talentlyft.com/en/blog/article/207/the-role-of-artificial-intelligence-ai-inrecruitment

Moon. Clients. 2020, https://askformoon.io/

Mya. Our clients. Retrieved October 2, 2020, from https://www.mya.com/

Rangaiah, M. What is HR Analytics? Role, Challenges and Applications. 2020, https://www.analyticssteps.com/blogs/what-hr-analytics-role-challenges-and-applications

Selectsoftwarereviews. The Top 13 Best Recruiting and HR Chatbots. 2020, https://www.selectsoftwarereviews.com/buyer-guide/hr-chat-bots

Slintel. Applicant tracking software. 2020, https://www.slintel.com/tech/recruitment/taleomarket-share

Talkpush. Customers. 2020, https://talkpush.com/?ssrid=ssr

Tech Funnel. Best Applicant Tracking Systems to Look Up in 2020. 2020, https://www.techfunnel.com/hr-tech/best-applicant-tracking-systems/

Verlinden N. HR Digital Transformation: The 6 Stages of Successful HR Transformation. 2020, https://www.digitalhrtech.com/category/digital-hr/

Vulpen E. V. Top 9 HR Analytics Tools. 2020, https://www.analyticsinhr.com/blog/hranalytics-tools/

Wadeandwendy. AI Recruiter on demand. 2020, https://wadeandwendy.ai/?ssrid=ssr

\section{Hima Jyothi ORCID ID: 0000-0003-2521-1237}


Towards Excellence: An Indexed, Refereed \& Peer Reviewed Journal of Higher Education / Ms. Hima Jyothi \& Ms. Salini Rosaline/ Page 76-93

VIT-AP School of Business, VIT-AP University, Amaravati- 522237, AP, INDIA

E-Mail: himajyothi.20phd7062@vitap.ac.in

\&

Salini Rosaline

ORCID ID: 0000-0003-4674-8551

VIT-AP School of Business, VIT-AP University, Amaravati- 522237, AP, INDIA

E-Mail: salini.rosaline@vitap.ac.in 